\title{
Pre Extension Demonstration of Improved Common Bean (Phaseolus Vulgaris (1.)) with its Full Packages in Gamogofa and Segen Area Peoples Zone, SNNPRs, Ethiopia
}

\author{
Solomon Yokamo* and Walelegn Wotro \\ South Agricultural Research Institute, Arbaminch Agricultural Research Center, Ethiopia
}

Submission: July 05, 2018; Published: July 26, 2018

*Corresponding author: Solomon Yokamo, South Agricultural Research Institute, Arbaminch Agricultural Research Center, Ethiopia, Tel: +251925701072, email: solomonyokamon@gmail.com

\begin{abstract}
Three varieties of common bean i.e. hawassa dume, tatu and remeda were demonstrated with its full packages on $100 \mathrm{~m}^{2}$ area at three different FTCs and 16 model farmers farm. Necessary inputs were delivered to farmers from the Arbaminch Agricultural Research Center and relevant researchers can follow-up and works in close relationship with farmers. Yield data, partial budget analysis, famers perception and preferences were collected throughout the demonstration stages. The average yield performances of the hawassa dume, tatu and remeda were $26.33 \mathrm{qt} / \mathrm{hec}, 21.16 \mathrm{qt} / \mathrm{hec}$ and $28.80 \mathrm{qt} / \mathrm{hec}$ respectively. The net benefit that were obtained from hawassa duume, tatu and remeda were 14,197ETB, 9544 ETB and 16,420 ETB respectively. Finally, the demonstration sites were visited by organized farmers field day and farmers select those varieties by different criteria and judge Tatu and hawassa duume have better disease resistance potential, drought tolerant and its earliness potential. Finally, it is better to scale up both tatu and hawassa dume in larger scale to enhance adoption and diffusion and to boost production and productivity of the variety to larger scales.
\end{abstract}

Keywords: Demonstration; Farmers Field Day; Varieties; Scale up; FRG

\section{Introduction}

Legumes are the major sources of protein in Ethiopia where common bean (Phaseolus vulgaris L.) takes large proportion next to faba bean and field pea [1-4]. It is one of the major grain legumes widely cultivated by the smallholder farmers in the Southern Nation, Nationalities and People's Region (SNNPR). Common bean (Phaseolus vulgaris $\mathrm{L}$ ) is an important traditional pulse in Ethiopia particularly in the Southern region of Gamo gofa and Konso districts. It is a basic component of cropping systems of small scale farmers and diets of people of Ethiopia as in many other countries in east, central and southern Africa. Due to its nutrients and commercial potential, common bean holds great promise for fighting hunger, increasing income and improving soil fertility in Sub Saharan Africa. It is both a food crop and an important source of cash. The importance of dry bean as a market crop varies within and across production areas. In the Rift Valley, more than $90 \%$ of beans are marketed whereas in the eastern zone the crop is grown both for food and cash. Bean production areas in Ethiopia can be broadly classified into four agro-ecological zones: the central, eastern, southern and western zones grouped according to altitudes, rainfall, soil, production systems and geographical locations. Production constraints, both biotic and abiotic are specific, though some e. g. local varieties with low potential yield and susceptibility to pest and diseases are common to all zones. Similarly, preferences and types of bean grown vary in different zones. It is among world's most important food legume for direct human consumption as well as for international market to earn foreign currencies. Common bean is an important pulse crop grown in different parts of Ethiopia, especially in Southern Region, depending on climatic and socio-economic factors. Therefore, common bean is the principal grain legume in Ethiopia.

While in Ethiopia, where $73.4 \%$ of the common bean production is used for household consumption (CSA 2011/12), its importance as source of income for smallholder farmers has increased over the years. The leading destinations for Ethiopian common beans are European, Middle East, African and Far East countries. Ethiopia exports red and navy beans, much of which, are produced by smallholder farmers. Red bean exports account for more than $10 \%$ of the country's common bean volume while navy beans accounts for $90 \%$ [5]. Colored bean accounts for 
the largest share of consumption in Ethiopia. The lines were developed with the objectives of developing locally adaptive genotypes with high market value and higher resistance/ tolerance to major common bean diseases and insect pests in Ethiopia.

The National average yield of common beans is low ranging from 0.5 to 0.8 tone ha-1, which is far below the corresponding yield recorded at research sites (2.5-3 tones ha-1) using improved varieties. The low national mean yield observed for common bean could be attributed to various constraints related to low adoption of improved agricultural technologies, drought, and lack of improved varieties, poor cultural practices, disease, and environmental degradation. In essence of things, the generation and transfer of technologies is not an end in itself. Therefore, increasing productivity and production of common bean will be realized if and only if the farmers adopt the technologies that are developed by research. However, the genetic potential yields of the varieties have to be maintained to boost production and productivity to improve their income and livelihood.

In our region, many farmers uses more of local variety that are available on their hands than improved variety and the production and productivity were low. So, to overcome this problems, demonstrating early maturing, disease resistance, drought tolerant and high yielder variety are the main tools to enhance diffusion and increase production and productivity of the common bean in the selected areas [5-7].

\section{Objective}

a. To enhance the rapid diffusion and adoption of newly released common bean varieties to boost production and productivity.

b. To collect farmers preferences and feedback information.

c. To study direct cost benefit analysis of the variety.

\section{Methodology}

\section{Site and Farmers Selection}

For preextension demonstration of common bean variety Arbaminch Zuria woreda from Gamogofa Zone and Konso Woreda from Segen area peoples zone were selected. Three Kebeles were selected (Gaho and Fasha from Konso woreda and Shara from Arbaminch Zuria Woreda) purposively based on the relevant agro-ecology for the specific commodity. Sixteen (16) participant farmers (beneficiaries) were screened based on the willingness to participate in the demonstration works and the availability of sufficient farm land. Farmers research group (FRG) were organized to capacitate farmers through different trainings and experience sharing $[8,9]$.

\section{Implementation Procedure}

Ten by ten $\left(10 * 10=100 \mathrm{~m}^{2}\right)$ plot size area was prepared for each variety (Remeda, Tatu and Hawassa Dume) by inter and intra spacing of $40 \mathrm{~cm}$ and $10 \mathrm{~cm}$ respectively and $100 \mathrm{~kg} / \mathrm{ha}$ seed rate were used and $100 \mathrm{~kg}$ NPS fertilizer applied. The varieties were tested for their adaptation to our area by Arbaminch Agricultural Research Center (AMARC). The seeds were supplied by the project and distributed by AMARC in collaboration with the woreda experts and Development Agents of the respective kebeles. As part of the intervention activities, training on agronomic practices was given to farmers, DAs and experts. Finally, in order to evaluate the performance and final outputs of the varieties and share the lessons with different stakeholders', field days were organized in the fields of beneficiary farmers and technologies were promoted to mass through different media. Kebele is the smallest administrative units in Ethiopia.

\section{Data Collection Methods}

Both primary and secondary data were collected from various sources using different methods. The agronomic data were collected by the researchers directly from the field. The data on grain yield of the varieties were taken from $10 \mathrm{~m} * 10 \mathrm{~m}=$ $100 \mathrm{~m} 2$. The data were collected from all plots of the beneficiary farmers. In addition, perception data of the varieties were collected using focus group discussion during evaluation periods. The perception data on the varieties attributes were grouped in to; Seed emergence, Disease and pest resistance, Suitability for inter cropping, Earliness, Taste when mixed with other dishes, Leaf shading (manuring), number of pods per plant, number of seed per pod, Seed size, Yield, Seed color, taste, marketability and productivity. The respondents were responding their perception level on the relative advantage of each characteristics of the variety compared to local/previously introduced varieties. Secondary information was collected from the respective kebele and worked as Office of agriculture and rural development office of the woreda.

\section{Data Analysis}

All data were collected from the field and analyzed through different methods. Oneway ANOVA, Genstat software, simple descriptive statistics such as mean, CIMMYT partial budget analysis and pair wise and matrix rankings were used to analyze farmers preferences criteria.

\section{Results and Discussion}

\section{Yield Performance}

Yield Performance of Farmers Field: Yield data were collected from farmers field and the yield performance were shown below the Table 1 . The average yield performance of Hawassa dume was 17.94 quintal per hectare, that of Tatu was 14.84 quintal/hectare and Remeda was 21.57 quintals per hectare. Remeda shows better yield performance in all location than other variety.

Yield Performance of FTCs: The variety were sown in farmers training center (FTCs) because of FTCs serves as a school without wall and farmers who doesn't implement on their farms can learn and evaluate the varieties and builds their capacity to solve their problems by themselves for further. So, the 
demonstration works implemented in three FTCs for the sake of demonstrating the common bean varieties for nonparticipant farmers with in and around the Kebele. The collected yield data was shown below the table. Table 2 Yield Performance of FTCs. The average yield performance of Hawassa duume was 26.33 quintal per hectares, Tatu was 21.16 quintal per hectare and that of Remeda were 28.8 quintals per hectare. Remeda gave high yield both on farmers field and FTCs (Table 2).

1 Quintal $=100 \mathrm{~kg}$

Table 1: Yield Performance of Farmers Field.

\begin{tabular}{|c|c|c|c|c|}
\hline \multirow{2}{*}{ Farmers } & \multirow{2}{*}{ Location } & \multicolumn{3}{|c|}{ Variety Yield in Quintal (1quintal=100k.g) } \\
\cline { 3 - 5 } & & Hawassa Dume & Tatu & Remeda \\
\hline F1 & Fasha & 16 & 10 & 17 \\
\hline F2 & Fasha & 20 & 17 & 21 \\
\hline F3 & Fasha & 22 & 6 & 25 \\
\hline F4 & Fasha & 16 & 7 & 19 \\
\hline Mean & & $\mathbf{1 8 . 5 0}$ & $\mathbf{1 0}$ & $\mathbf{2 0 . 5}$ \\
\hline F5 & Gaho & 11 & 18 & 17 \\
\hline F6 & Gaho & 10 & 7 & 22 \\
\hline F7 & Gaho & 16 & 15 & 19 \\
\hline F8 & Gaho & 13 & 12 & 22 \\
\hline F9 & Gaho & 20 & 19 & 23 \\
\hline F10 & Gaho & 15 & 14 & 29 \\
\hline F11 & Gaho & 25 & 24 & 22 \\
\hline F12 & Gaho & 23 & 21 & 15.55 \\
\hline
\end{tabular}

\begin{tabular}{|c|c|c|c|c|}
\hline F13 & Gaho & 21 & 19 & 23 \\
\hline Mean & & $\mathbf{1 7 . 1 1}$ & $\mathbf{1 6 . 5 6}$ & $\mathbf{2 1 . 3 9}$ \\
\hline F14 & Shara & 17 & 22 & 24 \\
\hline F15 & Shara & 24 & 12.5 & 20.5 \\
\hline F16 & Shara & 18 & 14 & 26 \\
\hline Mean & & $\mathbf{1 9 . 6 7}$ & $\mathbf{1 6 . 1 7}$ & $\mathbf{2 3 . 5}$ \\
\hline \multirow{2}{*}{} & $\begin{array}{c}\text { Grand } \\
\text { Mean }\end{array}$ & 17.94 & 14.84 & 21.57 \\
\cline { 2 - 5 } & Stdv & 4.4 & 5.4 & 3.5 \\
\hline
\end{tabular}

Note: 1 Quintal $=100 \mathrm{~kg}$.

Table 2: Yield Performance of FTCs.

\begin{tabular}{|c|c|c|c|}
\hline \multirow{2}{*}{ Location(N=16) } & \multicolumn{3}{|c|}{ Yield performance of Variety } \\
\cline { 2 - 4 } & Hawassa Dume & Tatu & Remeda \\
\hline Fasha & 24 & 22 & 27 \\
\hline Gaho & 22.5 & 15.5 & 24 \\
\hline Shara & 32.5 & 26 & 35.5 \\
\hline Mean & 26.33 & 21.16 & 28.8 \\
\hline
\end{tabular}

Note: 1 Quintal $=100 \mathrm{~kg}$.

\section{Yield Increase and Advantage}

Tatu shows -4.18 quintal and $-22.33 \%$ yield decrease and yield advantage than standard checks. While, Remeda shows 3.37 quintal and $18.43 \%$ yield increase and yield advantage over standard checks respectively (Table 3).

Table 3: yield advantage and yield increases.

\begin{tabular}{|c|c|c|c|c|c|c|c|}
\hline \multirow{2}{*}{$\begin{array}{c}\text { Location } \\
(\mathrm{N}=16)\end{array}$} & \multicolumn{3}{|c|}{ Yields in Kg } & \multicolumn{2}{|c|}{ Yield Increase } & \multicolumn{2}{|c|}{ Yield Advantage (\%) } \\
\hline & H.dume(Standard check) & Tatu & Remeda & Tatu & Remeda & Tatu & Remeda \\
\hline Fasha & 1850 & 1000 & 2050 & -850 & 200 & -46 & 10.81 \\
\hline Gaho & 1711 & 1656 & 2139 & -55 & 428 & -3.2 & 25 \\
\hline Shara & 1967 & 1617 & 2350 & -350 & 383 & -17.8 & 19.47 \\
\hline Mean & 14.84 & 1484 & 2157 & -418.33 & 337 & -22.33 & 18.43 \\
\hline
\end{tabular}

Tatu shows -4.18 quintal and $-22.33 \%$ yield decrease and yield advantage than standard checks. While, Remeda shows 3.37 quintal and $18.43 \%$ yield increase and yield advantage over standard checks respectively.

\section{Rank Frequency}

Pair-Wise Ranking Matrix of Farmers' Selection Criteria: Pair-wise ranking of farmers selection criteria were done, and farmers compare the criteria and rank them in order of importance. The following table shows the pair-wise ranking of the selection criteria. Seed emergence(A), Disease and pest resistance (B), Drought tolerance(C), Earliness(D), No. of pods per plant(E), No. of seed per pod(F), Seed size(G), Yield(H), Seed color(I), Cooking time(J), Taste(K), Marketability(L) (Figure 1). Farmers select criteria as its importance; drought tolerance, seed color and marketability got the first place during selection. Yield, Number of seed per pod, and Seed size takes the next place. We have learnt that the farmers' selection criteria are beyond yield and most farmers give priority for qualitative traits. They give priority for seed color, marketability and drought tolerance than other traits.

Farmers Preferences: Farmers select common bean variety by different criteria. The criteria was set by farmers and adjusted by relevant researchers for the sake of clarity. According to the above table, farmers at konso rank Tatu variety at first, Hawassa duume at second and remeda variety at third places. While at Arbaminch Zuria district, farmers rank Hawassa duume at first, tatu at second and remeda at third. Generally, Farmers ranks tatu variety at first place by its excellent seed emergency, disease and 
pest resistances, high drought tolerances, earliness, number of seeds per pod and its marketability. Also farmers select Hawassa Dume as second by the criteria of high seed emergency rate, disease and pest resistances, earliness, seed size, seed color, cooking time, taste and its marketability. Farmers put Remeda as third position because of it doesnt resist drought and stays long at field for maturity compared with other varieties (Figure 2) (Table 4).

\begin{tabular}{|c|c|c|c|c|c|c|c|c|c|c|c|c|c|c|}
\hline $\begin{array}{c}\text { Selection } \\
\text { criteria }\end{array}$ & A & B & C & D & E & F & G & $\mathrm{H}$ & I & $\mathbf{J}$ & K & L & Points & Rank \\
\hline $\mathbf{A}$ & & B & C & A & $\mathrm{E}$ & $F$ & A & $\mathrm{H}$ & I & A & $\mathrm{K}$ & $\mathbf{L}$ & 3 & 6 \\
\hline B & & & $\mathrm{C}$ & B & B & B & G & $\mathrm{H}$ & I & $\mathrm{J}$ & $\mathrm{K}$ & L & 4 & 5 \\
\hline C & & & & C & C & C & C & C & C & $\mathrm{C}$ & C & L & 10 & 1 \\
\hline D & & & & & D & $F$ & G & $\mathrm{H}$ & I & D & $\mathrm{K}$ & L & 2 & 7 \\
\hline E & & & & & & $\mathrm{F}$ & G & $\mathrm{H}$ & I & $\mathrm{E}$ & $\mathrm{K}$ & $\mathrm{L}$ & 2 & 7 \\
\hline $\mathbf{F}$ & & & & & & & $\mathrm{F}$ & $\mathrm{H}$ & I & $\mathrm{F}$ & $\mathrm{F}$ & L & 6 & 3 \\
\hline G & & & & & & & & $\mathrm{H}$ & I & G & G & L & 5 & 4 \\
\hline H & & & & & & & & & I & $\mathrm{H}$ & $\mathrm{H}$ & L & 8 & 2 \\
\hline I & & & & & & & & & & I & I & I & 10 & 1 \\
\hline $\mathbf{J}$ & & & & & & & & & & & $\mathrm{K}$ & $\mathrm{L}$ & 1 & 8 \\
\hline K & & & & & & & & & & & & $\mathrm{L}$ & 5 & 4 \\
\hline L & & & & & & & & & & & & & 10 & 1 \\
\hline
\end{tabular}

Figure 1
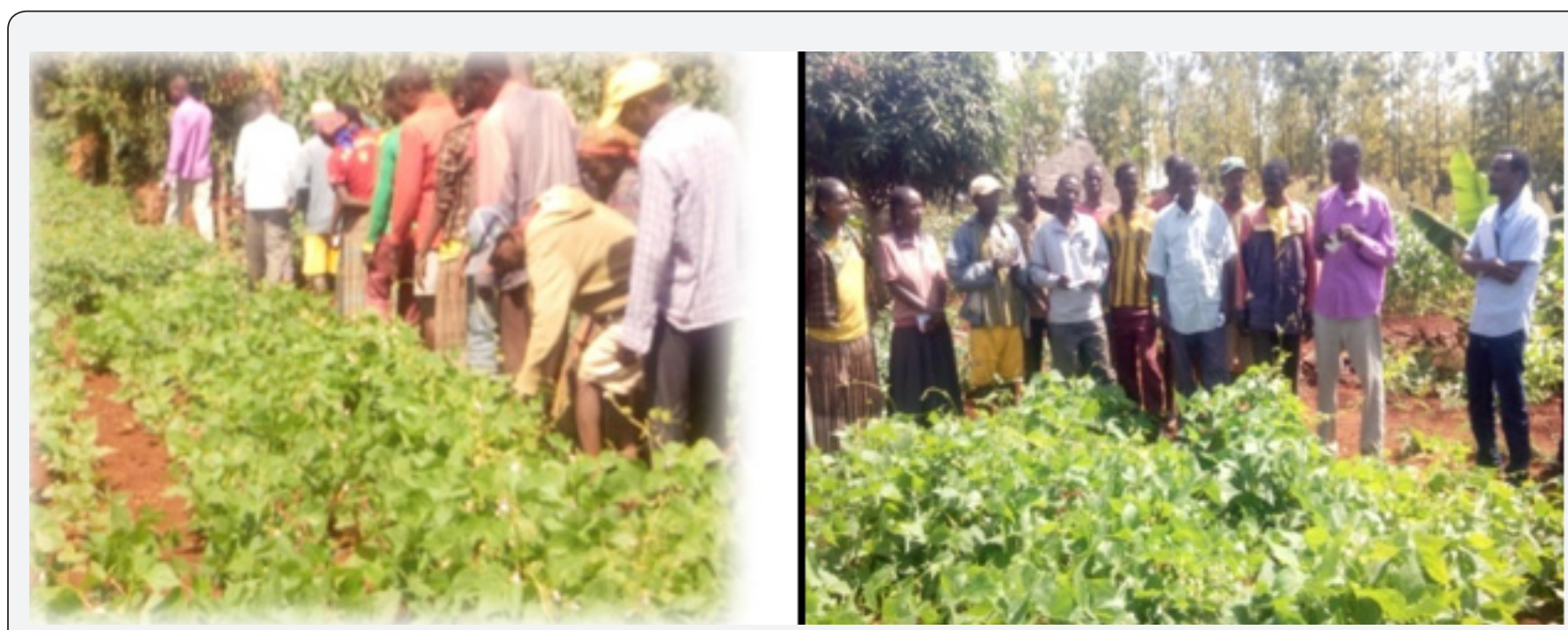

Figure 2

Table 4: Rank frequency.

\begin{tabular}{|c|c|c|c|c|c|c|c|c|c|c|}
\hline \multirow{3}{*}{ Variety } & \multicolumn{10}{|c|}{ Location } \\
\hline & \multicolumn{3}{|c|}{ Fasha } & \multicolumn{3}{|c|}{ Gaho } & \multicolumn{3}{|c|}{ Shara } & \multirow[b]{2}{*}{ Over al } \\
\hline & Total score & Mean Score & Rank & Total score & Mean Score & Rank & Total score & Mean Score & Rank & \\
\hline H.Duume & 38 & 3.2 & 2 & 34 & 2.9 & 2 & 45 & 3.8 & 1 & 2 \\
\hline Tatu & 44 & 3.7 & 1 & 43 & 3.6 & 1 & 39 & 3.3 & 2 & 1 \\
\hline Remeda & 35 & 3 & 3 & 31 & 2.6 & 3 & 36 & 3 & 3 & 3 \\
\hline
\end{tabular}




\section{Cost Benefit Analysis}

According to CIMMYT 1988, The yield obtained initially were adjusted at $-10 \%$ because of the adjusted yield for a treatment is the average yield adjusted downward by a certain percentage to reflect the difference between the experimental yield and the yield farmers could expect from the same treatment. Experimental yields, even from on-farm experiments under representative conditions, are often higher than the yields that farmers could expect using the same treatments (Table 5).

Table 5: Cost benefit analysis of common bean variety.

\begin{tabular}{|c|c|c|c|c|c|c|}
\hline \multirow{3}{*}{$\begin{array}{c}\text { S.N } \\
1 \\
\end{array}$} & \multirow{2}{*}{\multicolumn{2}{|c|}{ Items }} & \multirow{3}{*}{ Unit price/cost } & \multicolumn{3}{|c|}{ Varieties } \\
\hline & & & & \multirow{2}{*}{$\begin{array}{c}\text { Hawassa Dume } \\
2633\end{array}$} & \multirow{2}{*}{$\begin{array}{l}\text { Tatu } \\
2116\end{array}$} & \multirow{2}{*}{$\begin{array}{c}\text { Remeda } \\
2880\end{array}$} \\
\hline & Average yield (kg/hectare) & $\mathrm{kg}$ & & & & \\
\hline \multirow[t]{2}{*}{2} & Adjusted yield (-10\%) & $\mathrm{kg}$ & & 2369.7 & 1904.4 & 2592 \\
\hline & Total gain $(\mathrm{A})$ & Birr & & 23697 & 19044 & 25920 \\
\hline 3 & Seed Cost & $\mathrm{kg}$ & 37 & 3700 & 3700 & 3700 \\
\hline \multirow{3}{*}{4} & \multirow{3}{*}{ Fertilizer costs in kg } & NPS & 100 kg(12ЕТВ) & 1200 & 1200 & 1200 \\
\hline & & Urea & - & & & \\
\hline & & Total & 100 & 1200 & 1200 & 1200 \\
\hline 5 & Land preparation cost & ha & 800 & 800 & 800 & 800 \\
\hline \multirow{6}{*}{6} & \multirow{4}{*}{ Labor costs per day } & Sowing & 1 day*10 person*50 birr & 500 ЕТВ & 500 ЕТВ & 500 ЕТВ \\
\hline & & Weeding & 2 day*10 person*50 birr & 1000 & 1000 & 1000 \\
\hline & & Fertilizer application & 1day*6person*50birr & 300 & 300 & 300 \\
\hline & & $\begin{array}{l}\text { Harvesting, threshing and } \\
\text { transporting }\end{array}$ & 4 day*10person*50birr & 2000 & 2000 & 2000 \\
\hline & Total costs(B) & & & 9500 & 9500 & 9500 \\
\hline & Net Benefit(C) & & & 14,197 & 9544 & 16,420 \\
\hline
\end{tabular}

Management: If they manage the experimental variables. researchers can often be more precise and sometimes more timely than farmers in operations such as plant spacing of the plant, weed control or fertilizer application.

Plot size: Yields estimated from small plots often overestimate the yield of an entire field because of errors in the measurement of the harvested area and because the small plots tend to be more uniform than large fields.

Harvest Date: Researchers often harvest a crop at physiological maturity, whereas farmers may not harvest at the optimum time. Thus even when the yields of both researchers and farmers are adjusted to a constant moisture content, the researchers' yield may be higher, because of fewer losses to insects, birds, rodents, ear rots, or shattering.

Form of harvest: In some cases farmers' harvest methods may lead to heavier losses than result from researchers' harvest methods. This might occur, for example, if farmers harvest their fields by machine and researchers carry out a more careful manual harvest.

\section{Conclusion and Recommendation}

\section{Conclusion}

Preextension demonstration of common bean works were conducted in konso and Arbaminch Zuria Woreda with the objective of enhancing diffusion and adoption of the variety. The demonstration works were implemented at 16 farmers field and three FTCs at $100 \mathrm{~m} 2$ area. Hawassa dume, Tatu and Remeda varieties were demonstrated with $40 \mathrm{~cm} * 10 \mathrm{~cm}$ inter and intra row spacing and $100 \mathrm{~kg}$ seed rate were used. Training, sowing, evaluation \& continuous follow up and organization of field days were conducted and farmers evaluate and select the best performed varieties in their area according to their own criteria.

\section{Recommendation}

a. It is better to disseminate the preferred common bean technologies to a large number of farmers through scaling up to enhance diffusion and adoption of the variety.

b. Therefore, it is advisable to participate farmers in the Common bean demonstration from the very beginning and exploit their indigenous knowledge and selection criteria so as to develop and disseminate farmer preferred varieties.

c. To enhance production and productivity, Provision of training to farmers to apply technologies with its full packages including agronomic practices.

\section{Acknowledgement}

We thank the farmers and development agents DAs in the study without whose active participation this trial would have not been realized; SARI (southern agricultural research institute) 
and Arbaminch agricultural research center for material and financial support; providing seed and technical backup.

\section{References}

1. Asfaw A, Dauro D, Kimani PM (2004) Decentiralized participatory bean breeding in southern Ethiopia. In Proceedings of the $11^{\text {th }}$ conference of the crop sciences society of Ethiopia. Addis Ababa, Ethiopia.

2. CIMMYT (1988) From agronomic data to farmers recommendation.

3. CSA (2010) Crop production forecast sample survey, 2010/11 (2003 EC) Report on area and crop production forecast for major grain crops (for private peasant holding, meher season) Central Statistical Agency of Ethiopia, Addis Ababa, Ethiopia.

4. CSA (2011) Agricultural sample survey 2010/2011 (2003 EC) Report on area and production of major crops. Central Statistical Agency of Ethiopia, Addis Ababa, Ethiopia.

5. Fekadu Gurmu (2007) Participatory Varietal Selection of Haricot Bean (Phaseolus vulgaris L.) Varieties in Umbullo Wacho and Beresa Watersheds in the Southern Region.
6. Gemechu Keneni, Yohannes Gojjam, Kiflu Bedane, Chilot Yirga, Asgelil Didabe (2002) Towards Farmers Participatory Research. Attempts and achievements in the Central High lands of Ethiopia. In Proceedings of Client-Oriented Research Evaluation Workshop. Holleta Agricultural Research Center, Holleta, Ethiopia.

7. Graham PH, P Ranalli (1997) Common bean (Phaseolus vulgaris L) Field Crops Research 53: 131-146.

8. Joshi A, Witcombe JR (1996) Farmer participatory crop improvement 2. Participatory varietal selection: A case study in India. Experimental Agriculture 32(4): 461-477.

9. Operational Research and Capacity Building for Food Security and Sustainable Livelihoods. Proceedings of Irish Aid Supported Operational Research Review Workshop. Hawassa University, Awassa, Ethiopia.

\section{Your next submission with Juniper Publishers will reach you the below assets}

- Quality Editorial service

- Swift Peer Review

- Reprints availability

- E-prints Service

- Manuscript Podcast for convenient understanding

- Global attainment for your research

- Manuscript accessibility in different formats

( Pdf, E-pub, Full Text, Audio)

- Unceasing customer service

Track the below URL for one-step submission https://juniperpublishers.com/online-submission.php 